\title{
FAKTOR PENDUKUNG DAN PENGHAMBAT STRATEGI DAKWAH PARTAI KEADILAN SEJAHTERA (PKS) DI SULAWESI TENGGARA SERTA SOLUSINYA
}

\author{
Iyatna Supriatna \\ Muliaty Amin \\ Usman Jasad \\ iyatna.s@gmail.com
}

\begin{abstract}
Abstrak: Tujuan penelitian ini mengurai tentang faktor pendukung dan penghambat strategi dakwah Partai Keadilan Sejahtera (PKS) di Sulawesi Tenggara serta solusinya. Penelitian ini adalah penelitian lapangan (field research) yang bersifat deskriptif kualitatif. Lokasi penelitian bertempat di Kota Kendari Sulawesi Tenggara yaitu strategi dakwah PKS di kota Kendari, Kab.Muna dan Anggota legislatif. Pendekatan yang digunakan dalam penelitian ini adalah pendekatan normatif, dakwah, komunikasi dan pendekatan sosiologis. Sumber data primer berasal dari hasil wawancara peneliti dengan pengurus inti Partai Keadilan Sejahtera di Kota Kendari yakni ketua umum dan sekretaris umum, dan ketua bidang dakwah DPW Sulawesi Tenggara, sekretaris DPD PKS Kab.Muna dan anggota legislatif, tokoh masyarakat, tokoh pemuda serta dokumentasi mengenai pelatihan yang pernah diikuti oleh para kader. Data dikumpulkan melalui observasi, wawancara dan dokumentasi dengan instrumen masing-masing sesuai metodenya. Analisis data dilakukan melalui reduksi data, penyajian data, dan penarikan kesimpulan. Data diuji keabsahannya dengan triangulasi sumber dan triangulasi teknik.

Hasil penelitian menunjukkan faktor pendukung dakwah siyasah sebagai strategi dakwah Partai Keadilan Sejahtera (PKS) di Sulawesi Tenggara meliputi partisipasi kader dalam memanfaatkan partai politik, kompotensi kader, materi yang disampaikan, media dan waktu yang digunakan, metode yang digunakan, adanya dukungan dari masyarakat dan pemerintah setempat. Adapun faktor penghambat meliputi kurangnya pemahaman kader, usia kader yang relatif muda, masih lemahnya komunikasi yang baik dan kontinyu dengan masyarakat, adat atau tradisi masyarakat dan letak geografis. Dan solusi faktor penghambat dalam menerapkan dakwah siyasah sebagai stategi dakwah Partai Keadilan Sejahtera (PKS) di Sulawesi Tenggara yakni dengan membangun kekokohan kader. Langkah-langkah solutif dalam membangun kekokohan tersebut antara lain: membangun kekokohan ma'nawiyah dalam hal ini membangun kekuatan ruhiyah untuk menjaga keikhlasan dalam medan dakwah. Kekokohan fikriyah yakni mempunyai wawasan dan keilmuan yang memadai agar mampu berinteraksi dengan dunia yang semakin maju. Selain itu, membangun kekokohan da'awiyah maksudnya setelah kokoh ruhiyah dan fikriyahnya maka selanjutnya menghidupkan roda dakwah sepanjang hidup. Serta kekokohan jasadiyah yaitu energi yang optimal dan kebugaran jasmani agar dapat melaksanakan dan memikul beban dakwah..
\end{abstract}

Kata Kunci: Strategi Dakwah; Partai Keadilan Sejahtera 


\section{PENDAHULUAN}

Salah satu kekuatan sosial politik yang menjadi gerakan dakwah yaitu Partai Keadilan Sejahtera (PKS). PKS berdiri sejak tahun 1999 yang mulai memunculkan eksistensinya sebagai kekuatan politik baru dengan nama Partai Keadilan, kemudian Partai Keadilan Sejahtera, dimana sebelumnya dikenal oleh masyarakat sebagai organisasi tanpa bentuk. Tidak lama setelah rezim orde baru tumbang. Sepanjang perkembangan Partai Keadilan (PK) dan PKS, kader-kader partai berusaha menempatkan dakwah dan politik sebagai elemen yang tidak terpisahkan. ${ }^{1}$

PKS lahir melalui gerakan sosial bernama Tarbiyah yang kemudian bermutasi menjadi partai politik. Basis sosial partai tersebut ialah kelompok muslim terdidik, muda dan kelas menengah kota. Tidak seperti partai politik lain, PKS selalu mampu mendulang simpati publik dengan memobilisasi kader dan simpatisannya untuk melakukan kegiatan bakti sosial secara terus-menerus dan tidak hanya menjelang pemilu. PKS tampil berbeda melalui sistem kaderisasi yang terorganisir dan sistematis serta meniscayakan komitmen dan keterlibatan aktif para kadernya. Kegiatan-kegiatan keagamaan yang rutin diselenggarakan seperti halaqah dan liqo tetap menjadi aspek-aspek penting dalam kehidupan partai dan anggota-anggotanya. ${ }^{2}$ Halaqah secara sederhana dalam istilah kaderkader PKS yaitu kelompok pengajian kaderisasi untuk para kader maupun pendukung yang biasanya beranggotakan 8-12 orang yang dikelola oleh seorang murabbi (guru) dan anggota pengajian dikenal dengan istilah mutarabbi. Sedangkan liqo dalam bahasa arab artinya pertemuan, yang esensinya sama dengan halaqah yakni istilah yang digunakan untuk menyebut secara umum pertemuan kelompok pengajian kaderisasi PKS. Kader yang mengabaikan loyalitas dan komitmen total terhadap nilai-nilai dakwah akan sulit berkembang di dalam partai. Kehidupan di internal PKS amat kaya dan intensif. Seluruh aspek-aspek internal ini adalah manifestasi dari sebuah partai yang juga memerankan diri sebagai gerakan sosial-keagamaan.

Sebagaimana gerakan-garakan Islamis lainnya, PKS lahir dari diskusidiskusi kecil dikalangan mahasiswa beberapa universitas yang kemudian bertransformasi menjadi gerakan politik. PKS muncul sebagai gerakan sosial Islam yang masih tetap mempertahankan karakter dasarnya dengan menambah kapasitas organisasi dan sumber dayanya. Yang mana dimulai dengan fase dakwah kampus, pembentukan gerakan mahasiswa dan gerakan politik. ${ }^{3}$

Partai Keadilan Sejahtera merupakan salah satu partai yang menjadikan politik sebagai sarana (washilah) dalam menegakkan amar ma'ruf nahy munkar.

${ }^{1}$ La Ode Muh. Dasnah (42 tahun), Ketua Bidang Dakwah dan Staf Ahli DPRD Provinsi Sulawesi Tenggara, Observasi dan Wawancara, 25 Juni 2015.

${ }^{2}$ La Ode Muh. Dasnah (42 tahun), Ketua Bidang Dakwah dan Staf Ahli DPRD Provinsi Sulawesi Tenggara, Observasi dan Wawancara, 25 Juni 2015.

${ }^{3}$ La Ode Muh. Dasnah (42 tahun), Ketua Bidang Dakwah dan Staf Ahli DPRD Provinsi Sulawesi Tenggara, Wawancara, 25 Juni 2015. 
Partai politik yang PKS gunakan tersebut sebagai strategi agar tetap dapat menjalankan misinya dalam sistem demokrasi di Indonesia seperti saat ini. Sebagaimana hal tersebut dijabarkan dalam visi dan misi yang telah diusung oleh PKS.

Tulisan ini akan mengurai tentang faktor pendukung dan penghambat strategi dakwah Partai Keadilan Sejahtera (PKS) di Sulawesi Tenggara serta solusinya.

\section{TINJAUAN TEORETIS}

\section{A. Visi Misi Partai Keadilan Sejahtera}

Visi PKS adalah terwujudnya masyarakat madani yang adil, sejahtera dan bermartabat. Masyarakat madani adalah masyarakat berperadaban tinggi dan maju yang berbasiskan pada nilai-nilai, norma, hukum, moral yang ditopang oleh keimanan; menghormati pluralitas, bersikap terbuka dan demokratis; dan bergotong royong menjaga kedaulatan Negara. Pengertian genuine dari masyarakat madani itu perlu dipadukan dengan konteks masyarakat Indonesia di masa kini yang merealisasikan Ukhuwah Islamiyyah (ikatan keislaman), Ukhuwah Wathaniyyah (ikatan kebangsaan) dan Ukhuwah Basyariyyah (ikatan kemanusiaan) dalam bingkai NKRI. ${ }^{4}$

Perjuangan untuk mewujudkan masyarakat madani, baik secara struktural maupun kultural, sebagai bagian dari dakwah dalam maknanya yang historis, positif dan objektif bagi umat Islam dalam bingkai NKRI adalah bagian dari upaya merealisasikan tujuan didirikannya PKS sebagaimana dicantumkan dalam Anggaran Dasar PKS.

Adapun misi PKS yakni:

1. Mempelopori reformasi sistem politik, pemerintah dan birokrasi, peradilan, dan militer untuk berkomitmen terhadap penguatan demokrasi. Mendorong penyelenggara sistem ketatanegaraan yang sesuai dengan fungsi dan wewenang setiap lembaga agar terjadi proses saling menguasai. Menumbuhkan kepemimpinan yang kuat, mempunyai kemampuan membangun solidaritas masyarakat untuk berpartisipasi dalam seluruh dinamika kehidupan berbangsa dan bernegara, yang memiliki keunggulan moral, kepribadian, dan intelektualitas. Melanjutkan reformasi birokrasi dan lembaga peradilan dengan memperbaiki sistem rekrutmen dan pemberian sanksi penghargaan, serta penataan jumlah pegawai negeri dan memfokuskannya pada posisi fungsional, untuk membangun birokrasi yang bersih, kredibel, dan efisien. Penegakan hukum yang diawali dengan kebersihkan aparat penegaknya dari perilaku bermasalah dan koruptif. Mewujudkan kemandirian dan pemberdayaan industri pertahanan nasional.

\footnotetext{
4“"PKS Visi dan Misi”, Situs Resmi Dewan Pengurus Pusat Partai Keadilan Sejahtera. www. Pks.or.id/mobile/content.html? (19 Mei 2015).
} 
Mengembangkan otonomi daerah yang terkendali serta berorientasi pada semangat keadilan dan proporsionalitas melalui musyawarah dalam lembaga-lembaga kenegaraan di tingkat pusat, provinsi dan daerah. Menegaskan kembali sikap bebas dan aktif dalam mengupayakan stabilitas kawasan dan perdamaian dunia berdasarkan prinsip kesetaraan, saling menghormati, saling menguntungkan dan penghormatan terhadap martabat kemanusiaan. Menggalang solidaritas dunia demi mendukung bangsabangsa yang tertindas dalam merebut kemerdekaannya. ${ }^{5}$

Misi yang pertama tersebut merupakan bentuk awal dalam mewujudkan visi partai melalui langkah-langkah struktural.

2. Mengentaskan kemiskinan, mengurangi pengangguran, dan meningkatkan kesejahteraan seluruh rakyat melalui strategi pemerataan pendapatan, pertumbuhan bernilai tambah tinggi, dan pembangunan berkelanjutan, yang dilaksanakan melalui langkah-langkah utama berupa pelipatgandaan produktifitas sektor pertanian, kehutanan dan kelautan, peningkatan daya saing industri nasional dengan pendalaman struktur dan upgrading kemampuan teknologi dan pembangunan sektor-sektor yang menjadi sumber pertumbuhan baru berbasis resources dan knowledge. Semua itu dilaksanakan di atas landasan (filosofi) ekonomi egaliter yang akan menjamin kesetaraan atau evaluasi yang sederajat antara pemilik modal dan pelaku usaha, dan menjamin pembatasan tindakan spekulasi, monopoli dan segala bentuk kriminalitas ekonomi yang dilakukan oleh penguasa modal dan sumber-sumber ekonomi lain untuk menjamin terciptanya kesetaraan bagi seluruh pelaku usaha. ${ }^{6}$

Partai Keadilan Sejahtera (PKS) melihat bahwa kemiskinan merupakan salah satu masalah utama bangsa Indonesia yang harus segera diselesaikan.

3. Menuju pendidikan yang berkeadilan dengan memberikan kesempatan yang seluas-luasnya bagi seluruh rakyat Indonesia. Membangun sistem pendidikan nasional yang terpadu, komprehensif dan bermutu untuk menumbuhkan SDM yang berdaya saing tinggi serta guru yang profesional dan sejahtera. Menuju sehat paripurna untuk semua kelompok warga, dengan visi sehat badan, mental spiritual, dan sosial sehingga dapat beribadah kepada Allah swt untuk membangun bangsa dan Negara, dengan cara mengoptimalkan anggaran kesehatan dan seluruh potensi untuk mendukung pelayanan kesehatan yang berkualitas. Mengembangkan seni dan budaya yang bersifat etis dan religius sebagai faktor penentu dalam membentuk karakter bangsa yang tangguh, disiplin kuat, etos kerja kokoh, serta daya inovasi dan kreativitas tinggi. Terciptanya masyarakat sejahtera,

\footnotetext{
5"PKS Visi dan Misi", Situs Resmi Dewan Pengurus Pusat Partai Keadilan Sejahtera. www. Pks.or.id/mobile/content.html? (19 Mei 2015).

"“PKS Visi dan Misi", Situs Resmi Dewan Pengurus Pusat Partai Keadilan Sejahtera. www. Pks.or.id/mobile/content.html? (19 Mei 2015).
} 
melalui pemberdayaan masyarakat yang dapat mewadahi dan membantu proses pembangunan berkelanjutan. ${ }^{7}$

Visi dan misi tersebut tentu bukan hal yang mudah untuk merealisasikannya. Berbagai hambatan dan tantangan selalu ada bahkan sudah menjadi sebuah Sunnatullah bahwa jalan dakwah merupakan jalan yang sangat ramai dipenuhi onak dan duri.

PKS meyakini bahwa pembangunan merupakan hak sekaligus kewajiban masyarakat, bukan hanya Negara. Karenanya pemberdayaan masyarakat, baik dalam aspek politis maupun ekonomis, akan mengantarkan rakyat pada posisi sejajar sebagai mitra pemerintah, yang duduk satu meja bersama-sama untuk mencapai situasi saling menguntungkan. PKS memandang partisipasi total masyarakat madani, pengusaha, pemerintah serta kerjasama internasional. Yang merupakan lintas komponen dan aktor adalah sebuah keniscayaan dalam mengelola pembangunan. Semua itu dilaksanakan dalam kerangka yang bersifat integral, global dan universal menuju keadilan dan kesejahteraan. ${ }^{8}$

Namun, hambatan dan tantangan itu muncul baik secara internal maupun eksternal. Seperti diketahui akhir-akhir ini di media massa banyak beredar isu yang menimpa partai maupun kader, yang dampaknya citra lembaga menjadi buruk di mata msyarakat.

Sebagaimana halnya PKS yang berada di Provinsi Sulawesi Tenggara, yang ibu kotanya adalah Kendari. Sulawesi Tenggara merupakan pemekaran dari Provinsi Sulawesi Selatan-Tenggara.

PKS (dulu PK) dideklarasikan di Kendari pada tanggal 27 September 1998. Para pendirinya Andi Mansyur, SS., Suharman, S.Psi, M.Si. Saat ini partai politik yang ada di Sulawesi Tenggara berjumlah 10, diantaranya PAN, Golkar, Demokrat, PDIP, Gerindra, PPP, Nasdem, Hanura, PKB termasuk PKS. ${ }^{9}$ Meskipun PKS telah mengalami stagnan dalam pertarungan politik khususnya diwilayah Sulawesi Tenggara, namun sampai saat ini PKS masih diperhitungkan sebagai salah satu partai berjargon Islam yang cukup berpengaruh besar dalam hidup dan kehidupan baik dalam lingkup pemerintahan maupun terhadap masyarakat luas.

Saat ini dalam lingkup parlemen anggota legislatif (aleg) yang berada di Dewan Perwakilan Rakyat Daerah (DPRD) Provinsi Sulawesi Tenggara berjumlah lima orang, yang mana mereka tersebar pada semua komisi. Sedangkan untuk DPRD Kota Kendari aleg PKS terdiri dari empat kursi.

\footnotetext{
7"PKS Visi dan Misi", Situs Resmi Dewan Pengurus Pusat Partai Keadilan Sejahtera. www. Pks.or.id/mobile/content.html? (19 Mei 2015).

"PKS Visi dan Misi", Situs Resmi Dewan Pengurus Pusat Partai Keadilan Sejahtera. www. Pks.or.id/mobile/content.html? (19 Mei 2015).

${ }^{9}$ La Ode Muh. Dasnah (42 tahun), Ketua Bidang Dakwah dan Staf Ahli DPRD Provinsi Sulawesi Tenggara, Wawancara, 25 Juni 2015.
} 
Secara internal sebagai sebuah organisasi politik selain memiliki suatu manhaj, PKS juga memiliki anggota atau kader. Dalam perjalanannya kader tentu mempunyai tingkat pemahaman yang berbeda-beda. Tingkat pemahaman seseorang bisa menentukan konsistensinya pada misi yang diemban oleh organisasi tersebut. Sebagaimana misi dakwah yang terus disuarakan PKS, dalam upaya mewujudkannya terdapat kader yang makin istiqomah dan tsiqoh akan tetapi disisi lain ada juga kader yang berguguran. Realitanya kader yang berguguran adalah orang-orang pertama yang menjadi kader dan memperjuangkan PKS semenjak dideklarasikan di tanah Sulawesi Tenggara. Serta ketergantungan terhadap tokoh-tokoh kharismatik. Secara eksternal, baik dikalangan elit politik maupun masyarakat luas masih memiliki persepsi bahwa PKS sama halnya dengan partai-partai politik lainnya baik itu partai yang berjargon dakwah dimana lahir terlebih dahulu maupun partai konvensional. Citra buruk yang diidap partai-partai di Indonesia partai macet atau bahkan tidak aktif setelah perhelatan pemilu selesai.

\section{B. Bentuk dan Konteks Dakwah}

Islam merupakan ajaran yang bersumber dari Allah SWT dan diturunkan melalui malaikat Jibril kepada Nabi dan Rasul-Nya Muhammad saw. Misi Islam adalah untuk membebaskan manusia dari segala bentuk pengabdian kepada makhluk, kemudian menjadi pengabdi Allah SWT semata. Wujud pengabdian kepada Allah SWT dengan tunduk kepada sistem Islam dan syariat Allah, sehingga seluruh umat manusia bernaung di bawah panji Islam dan kepemimpinan dunia dipegang oleh umat Islam demi tercapainya kebahagiaan dunia dan akhirat. Untuk itu setiap muslim mempunyai tugas mendakwahkan misi Islam tersebut kepada setiap orang dan mentarbiyahkannya sehingga terjadi perubahan kepribadian dari waktu ke waktu menjadi lebih baik.

Dalam menyampaikan pesan dakwah, dai harus berbicara dengan gaya bahasa yang berkesan, menyentuh dan komunikatif. Bahasa lisan yang harus digunakan dalam berdakwah yaitu perkataan yang jujur, solutif terhadap permasalahan yang dihadapi mad'u, menyentuh hati, santun, menyejukkan dan tidak provokatif serta tidak mengandung fitnah.

1. Bentuk-Bentuk Dakwah

Adapun macam-macam bentuk dakwah adalah:

a. Dakwah bi al-Lisan

Secara substantif, dakwah adalah ajakan yang bersifat Islami. Sedangkan kata lisan, dalam bahasa Arab berarti "bahasa". Maka dakwah bi al-Lisan meliputi ceramah, seminar, simposium, diskusi, khutbah, sarasehan, brain storming, obrolan dan sebagainya. ${ }^{10}$ Dakwah adalah proses mengkomunikasikan pesan-pesan Ilahiah kepada orang lain. Agar pesan itu dapat disampaikan dan

\footnotetext{
${ }^{10}$ Malik Idris, Strategi Dakwah Kontemporer, (Cet.I; Makassar: Sarwah Press, 2007), h.
} 
dipahami dengan baik maka diperlukan adanya penguasaan terhadap teknik berkomunikasi yang efektif.

Bahasa dakwah yang digambarkan dalam Al-Qur'an, yakni tegas dalam menetapkan urusan, dan halus cara penyelesaiannya. Pemilihan kata-kata yang tepat ketika berdakwah, diklasifikasikan Al-Qur'an dalam beberapa bentuk sesuai dengan siapa mad'u (objek dakwah) yang dihadapi, diantaranya:

1) Qaulan balighan (perkataan yang membekas pada jiwa). Al-quran memberikan tuntunan, bahwa redaksi seruan dakwah berbeda-beda tekanannya, tergantung siapa mad'unya. Kata baligh dalam bahasa Arab artinya sampai, kena sasaran, atau mencapai tujuan. Bila dikaitkan dengan qawl (ucapan atau komunikasi), maka baligh berarti fasih, jelas maknanya, terang, tepat mengungkapkan apa yang dikehendaki. ${ }^{11}$ Karena itu qaulan balighan dapat diartikan komunikasi yang efektif. Dai sebagai komunikator dituntut agar mampu berbicara yang efektif dalam menyampaikan pesan dakwahnya agar tepat mengenai sasaran.

2) Qaulan layyinan (perkataan yang lembut). Perkataan yang mengandung anjuran, ajakan, hendaklah menggunakan kata-kata yang lemah lembut, suara yang enak didengar, sikap yang bersahabat dan perilaku yang menyenangkan dalam menerukan agama Allah.

3)Qaulan ma'rufan (perkataan yang baik). Bermakna perkataan yang baik atau perkataan yang pantas. Dalam beberapa konteks al-Razi menjelaskan sebagaimana yang dikutip oleh Muliadi bahwa qaul ma'ruf adalah perkataan yang baik, menancap ke dalam jiwa, sehingga yang diajak bicara tidak merasa dianggap bodoh (safih), perkataan yang mengandung penyesalan ketika tidak bisa memberi atau membantu, perkataan yang tidak menyakitkan dan yang sudah dikenal sebagai perkataan yang baik.

4)Qaulan maisuran (perkataan yang ringan). Maisuran berasal dari kata yasara-yaisiru-yusran, yang artinya mudah. Atau diartikan ucapan yang menyenangkan, lawannya adalah ucapan yang menyulitkan. ${ }^{12}$ Dakwah dengan qaulan maisuran berarti pesan yang disampaikan itu sederhana, mudah dimengerti dan dipahami, tanpa memerlukan pemikiran yang mendalam.

5)Qaulan kariman (perkataan yang mulia). Setiap perkataan yang dikenal lembut, baik yang mengandung unsur pemuliaan dan penghormatan. ${ }^{13}$ Sedangkan pendekatan yang digunakan ialah dengan perkataan yang mulia, santun, penuh hormat, dan penghargaan, tidak menggurui, sebab kondisi fisik mereka yang mulai melemah membuat mudah tersinggung apabila menerima perkataan yang keras dan terkesan menggurui. Oleh karenanya, dai harus bersikap hormat terhadap mad'u yang tergolong usia lanjut seperti memperlakukan orang tua sendiri.

\footnotetext{
${ }^{11}$ Malik Idris, Strategi Dakwah Kontemporer, h. 72-73.

${ }^{12}$ Muliadi, Dakwah Inklusif, (Cet.I; Makassar: Alauddin University Press,2013), h. 94-101

${ }^{13}$ Muliadi, Dakwah Efektif: Prinsip, Metode dan Aplikasinya, (Makassar: Alauddin University Press,2012), h. 86.
} 


\section{b. Dakwah bi al-Qalam}

Dakwah bi al-Qalam ialah suatu kegiatan menyampaikan pesan dakwah melalui tulisan, seperti buku, majalah, jurnal, artikel, internet dan lain-lain. Karena dimaksudkan sebagai pesan dakwah, maka tulisan-tulisan tersebut tentu berisi ajakan atau seruan mengenai amar ma'ruf dan nahy munkar.

Di era sekarang, peluang dakwah di internet terbuka lebar. Berdakwah lewat internet bisa dengan membuat blog. Keunggulan internet terletak pada kecepatan akses dan jangkauan jaringannya yang luas. Dari sinilah, para dai dituntut tidak hanya memiliki kemampuan bicara, namun juga kecakapan menuangkan gagasan-gagasannya dalam sebuah tulisan.

\section{c. Dakwah bi al-Hal}

Dakwah bi al-Hal adalah bentuk ajakan kepada Islam dalam bentuk amal, kerja nyata, baik yang sifatnya seperti mendirikan lembaga pendidikan Islam, kerja bakti, mendirikan bangunan keagamaan, penyantunan masyarakat secara ekonomis atau bahkan acara-acara hiburan keagamaan. Dakwah bi al-Hal yaitu berupa perilaku yang sopan sesuai dengan ajaran Islam, memelihara lingkungan, tolong-menolong sesama, misalnya membantu fakir miskin, memberikan pelayanan sosial dan sebagainya. $^{14}$

Misalnya dakwah dengan membangun rumah sakit untuk keperluan masyarakat sekitar yang membutuhkan keberadaan rumah sakit. Dakwah dengan pendekatan amal nyata merupakan aktivitas dakwah yang harus dilakukan bagi aktivis dakwah, sehingga dakwah tidak hanya dipahami sebagai ceramah atau dakwah bi al-Lisan saja. Karena sesungguhnya dakwah juga dapat dilakukan melalui tindakan atau amal nyata yang dilakukan sesuai kebutuhan masyarakat.

\section{Bentuk-Bentuk Kegiatan Dakwah}

a. Tabligh Islam

Tabligh merupakan salah satu dimensi dakwah. Ia merupakan suatu penyebarluasan ajaran Islam yang memiliki ciri-ciri tertentu yang bersifat insidental, oral, massal, seremonial bahkan kolosal. Tabligh adalah sebuah upaya yang merubah suatu realitas sosial yang tidak sesuai ajaran Islam kepada realitas sosial yang islami dengan cara-cara yang telah digariskan oleh Allah dalam AlQuran dan As-Sunnah, atau dari al-waqi' al ijtima'iy al jahili menuju al waqi' al ijtima'iy al islami. ${ }^{15}$

b. Irsyad Islam

Secara bahasa irsyad adalah bimbingan, seperti teknik penyuluhan Islam, kesehatan mental, psikoterapi Islam dan sebagainya.

c. Tadbir Islam

\footnotetext{
${ }^{14}$ Malik Idris, Strategi Dakwah Kontemporer, h. 63.

${ }^{15}$ Aep Kusnawan, Ilmu Dakwah (Kajian Berbagai Aspek), (Bandung: Pustaka Bani Quraisy, 2004), h. 183-184.
} 
Tadbir berarti pengurusan, pengelolaan (management), seperti pengembangan lembaga dakwah, pengembangan pelatihan dakwah, kebijakan dan strategi dakwah dan sebagainya.

d. Tathwir Islam

Secara bahasa artinya pengembangan, seperti pengembangan masyarakat Islam, peta sosial ekonomi umat dan sebagainya. ${ }^{16}$

\section{Konteks-Konteks Dakwah}

Dai dalam menyampaikan informasi ketika melakukan aktivitas dakwah, hendaklah baik, benar dan mendidik. Kualitas perkataan seseorang mencerminkan suasana hati. Lisan yang fasih, tegar dan penuh percaya diri merupakan gambaran kondisi hati seseorang yang tenang dan memiliki semangat untuk menyampaikan kebenaran. Perkataan yang tersusun rapi dari seorang dai, merupakan jembatan pembuka hati dan penggerak rasa bagi yang menerima panggilan/seruan.

Dalam proses penyampaian pesan dakwah kepada mad'u (objek dakwah) terdapat konteks (level) yaitu tingkatan-tingkatan dalam melaksanakan dakwah dilihat dari jumlah serta kondisi dan situasi mad'unya. Dalam buku dasar-dasar ilmu dakwah terdapat beberapa konteks di antaranya:

\section{a. Dakwah Nafsiyah}

Dakwah nafsiyah bisa dikatakan sebagai dakwah intrapersonal yaitu dakwah kepada diri sendiri, hal ini sangat perlu dilakukan bagi para dai karena seorang dai akan menjadi panutan bagi mad'unya. Dakwah nafsiyah dapat dilakukan dengan berbagai bentuk dan cara antara lain: menuntut ilmu, membaca, muhasabah al-nafs (introspeksi diri), taqarrub melalui dzikrullah (mengingat Allah) do'a (berdo'a) memelihara pencerahan jiwa, membersihkan jiwa, taubat. ${ }^{17}$

\section{b. Dakwah Fardhiyah}

Dakwah fardhiyah merupakan tingkatan setelah dakwah nafsiyah. Dakwah fardhiyah bisa disebut juga dakwah interpersonal yang berlangsung secara tatap muka (face to face) atau langsung tetapi tidak tatap muka atau bermedia.

c. Dakwak Fi'ah Qalilah

Dakwah fi'ah qalilah adalah dakwah yang dilakukan oleh seorang dai kepada kelompok kecil yaitu tiga hingga 20 orang, secara tatap muka dan bisa

\footnotetext{
${ }^{16}$ Aep Kusnawan, Ilmu Dakwah (Kajian Berbagai Aspek), h. 138.

${ }^{17}$ Muliaty Amin, Metodologi Dakwah, (Cet.I; Alauddin University Press: Makassar, 2013),
} h. 109 . 
berdialog secara langsung sehingga respon mad'u terhadap dai dan pesan dakwah yang disampaikan dapat diketahui seketika. ${ }^{18}$

\section{d. Dakwah Hizbiyah}

Dakwah hizbiyah adalah upaya yang dilakukan oleh sekelompok orang dalam upaya mengarahkan umat ke dalam perubahan yang lebih baik sesuai ajaran Islam. Kegiatan dakwah yang dilakukan melalui pengelolaan keorganisasian, baik organisasi majelis ta'lim, lembaga dakwah, lembaga ekonomi Islam, lembaga sosial Islam, lembaga politik Islam dan sebagainya. ${ }^{19}$

\section{e. Dakwah Ummah}

Dakwah ummah adalah proses dakwah yang dilaksanakan pada mad'u yang banyak, tidak bertatap muka dan monologis dengan media cetak atau elektronik atau tatap muka tetapi monologi seperti ceramah umum, atau khutbah.

f. Dakwah Syu'ubiyah Qabailiyah (Dakwah Antar Suku, Budaya Dan Bangsa)

Dakwah syu'ubiyah qabailiyah adalah proses dakwah yang berlangsung antar bangsa, suku, atau antar budaya dalam suatu kesatuan yang dapat berlangsung dalam konteks $1,2,3,4$ dan 5 budaya. ${ }^{20}$

Berdasarkan penjelasan di atas dapat dipahami bahwa interaksi antar unsur dakwah dalam masing-masing konteksnya menjadi wilayah kajian teoritik studi dakwah Islam yang sampai saat ini masih membutuhkan kajian yang mendalam.

\section{METODOLOGI PENELITIAN}

Penelitian ini adalah penelitian lapangan (field research) untuk mengamati fenomena atau kenyataan tentang dakwah siyasah sebagai strategi dakwah Partai Keadilan Sejahtera (PKS) di Sulawesi Tenggara. Dengan begitu, dapat dikatakan bahwa penelitian ini bersifat deskriptif kualitatif. Artinya penulis menganalisis dan menggambarkan penelitian secara objektif dan mendetail untuk mendapatkan hasil yang akurat.

Lokasi penelitian bertempat di Kota Kendari Sulawesi Tenggara yaitu strategi dakwah PKS di kota Kendari, Kab.Muna dan Anggota legislatif. Pemilihan lokasi ini sebagai objek penelitian didasarkan atas pertimbangan bahwa gerakan dakwah PKS menggunakan dakwah siyasah dengan sistem kaderisasi yang unik dan menarik serta memiliki keberagaman anggota atau kader dari segi usia, latar belakang pendidikan dan lain-lain juga didukung dengan masyarakat Sulawesi Tenggara yang masih mayoritas muslim. Penelitian ini penulis laksanakan sejak tanggal 8 juni sampai 27 Agustus 2015.

\footnotetext{
${ }^{18}$ Aep Kusnawan, Ilmu Dakwah (Kajian Berbagai Aspek), h. 130.

${ }^{19}$ Aep Kusnawan, Ilmu Dakwah (Kajian Berbagai Aspek), h. 197.

${ }^{20}$ Aep Kusnawan, Ilmu Dakwah (Kajian Berbagai Aspek), h.130.
} 
Pendekatan yang digunakan dalam penelitian ini adalah pendekatan normatif, dakwah, komunikasi dan pendekatan sosiologis. Sumber data primer berasal dari hasil wawancara peneliti dengan pengurus inti Partai Keadilan Sejahtera di Kota Kendari yakni ketua umum dan sekretaris umum, dan ketua bidang dakwah DPW Sulawesi Tenggara, sekretaris DPD PKS Kab.Muna dan anggota legislatif, tokoh masyarakat, tokoh pemuda serta dokumentasi mengenai pelatihan yang pernah diikuti oleh para kader. Sedangkan sumber data sekunder dalam bentuk dokumen yang telah ada yang dapat mendukung penelitian ini, seperti buku-buku yang menjelaskan tentang PKS, data dan dokumentasi penting yang menyangkut profil PKS, materi-materi dakwah dan data kader PKS yang menjadi anggota legislatif serta data base kader.

Data dikumpulkan melalui observasi, wawancara dan dokumentasi dengan instrumen masing-masing sesuai metodenya. Analisis data dilakukan melalui redukis data, penyajian data, dan penarikan kesimpulan. Data diuji keabsahannya dengan triangulasi sumber dan triangulasi teknik.

\section{HASIL DAN PEMBAHASAN}

Pemanfaatan dakwah siyasah sebagai strategi dakwah yang dilakukan oleh partai keadilan sejahtera (PKS) di Sulawesi Tenggara, sering dipengaruhi oleh berbagai faktor, baik faktor pendukung maupun faktor penghambat. Faktor internal yaitu faktor yang berasal dari dalam lingkup PKS, dan faktor eksternal yaitu faktor yang berasal dari luar PKS.

\section{Faktor Pendukung Dakwah Siyasah sebagai Strategi Dakwah Partai Keadilan Sejahtera (PKS) di Sulawesi Tenggara}

Berdasarkan hasil penelitian penulis, ada beberapa faktor yang penulis identifikasikan sebagai faktor pendukung strategi dakwah PKS di Sulawesi Tenggara, yaitu:

a. Partisipasi kader dalam memanfaatkan partai politik $^{21}$

Sebagaimana yang telah dijelaskan sebelumnya bahwa PKS memiliki tahapan-tahapan dakwah jauh sebelum mendirikan partai politik sebagai sarana dakwahnya atau dikenal dengan istilah mihwar mu'assasi (dakwah dengan melalui kelembagaan politik). Dimana sebelumnya berada pada mihwar tanzimi dan mihwar sya'bi. Jadi, partisipasi politk pada tahap mu'assasi ini menjadi bagian yang harus dilakukan untuk semakin memperkokoh eksistensi dakwah melalui kelembagaan Negara.

Kemampuan PKS untuk mendirikan partai politik tentu sudah mempertimbangkan segala hal termasuk salah sat unya adalah ketersediaan kaderkader dalam jumlah banyak yang memiliki keunggulan normatif dan aplikatif

${ }^{21}$ La Pili (37 tahun), Sekretaris MPW PKS dan Anggota DPRD Provinsi Sulawesi Tenggara, Observasi dan Wawancara, Raha, 25 Agustus 2015. 
serta penyebaran kader yang merata secara geografis. Adanya struktur kepengurusan di setiap Kecamatan yang ada bahkan sampai pada tingkat desa/kelurahan menjadi kekuatan tersendiri bagi strategi dakwah PKS. ${ }^{22}$

Berdasarkan hasil penelitian penulis ditemukan bahwa sudah terdapat kader-kader dakwah PKS di Sulawesi Tenggara yang membangun kepemimpinan di masyarakat dengan menjadi tokoh-tokoh adat maupun agama serta 9 orang kader yang melakukan kerja politik praktis di berbagai lembaga strategis seperti legislatif baik di tingkat provinsi maupun kota.

b. Kompetensi kader ${ }^{23}$

Kader adalah aset yang utama untuk aktivitas dakwah, sehingga dengan tersedianya kader dakwah yang berkualitas maka dakwah akan berkembang sesuai dengan marhalahnya. Jadi kompotensi kader merupakan salah satu faktor pendukung yang sangat penting dalam melaksanakan kerja-kerja dakwah. Secara lebih rinci proses mengembangkan potensi dan membentuk kepribadian kader dalam PKS dikenal dengan istilah tarbiyah.

Setelah mengamati dan melakukan penelusuran pada data dokumentasi ditemukan bahwa dalam proses pembentukan kepribadian setiap kader harus memenuhi 10 aspek yaitu salimul aqidah (bersih akidahnya), shahihul 'ibadah (benar ibadahnya), matinul khuluq (kokoh akhlaknya), qawiyyul jism (kuat fisiknya), mutsaqqaful fikr (berwawasan pemikirannya), qadirun 'alal kasbi (mampu berekonomi), munazhamun fi su'unihi (terorganisir segala urusannya), harishun 'ala waqtihi (cermat mengatur waktunya), mujahidun fi nafsihi (kuat kesungguhan jiwanya), dan naafi'un li ghairihi (bermanfaat bagi selainnya). Hal tersebut dilakukan untuk mempersiapkan kader yang kokoh secara ruhiyah, fikriyah, dan jasadiyah. Karena menurut mereka kader yang memiliki kebugaran jasmani tanpa disertai dengan kekuatan ruhiyah, maka tidak akan mampu melaksanakan kerja-kerja dakwah. Kekokohan ruhiyah merupakan daya dorong untuk melaksanakan kegiatan-kegiatan operasional dan beban dakwah. ${ }^{24}$

Oleh karena itu, dalam pembinaan terhadap kader-kadernya termasuk di Sulawesi Tenggara PKS selalu menekankan membangun kekuatan ruhiyah untuk menjaga keikhlasan dalam medan dakwah partai. Baik yang berkaitan dengan dimensi aqidah, ibadah dan akhlak. Begitupun dengan kekokohan fikriyah dalam perjalanan dakwah harus dipenuhi, sebab tanpa wawasan dan keilmuan yang memadai, kader dakwah tidak akan mampu berinteraksi dengan dunia kemajuan, era global dan teknologi informasi yang dihadapinya.

Kesepuluh aspek kualitas kader tersebut dicapai melalui berbagai kegiatan pembinaan di berbagai sarana yang digariskan oleh manhaj tarbiyah.

${ }^{22}$ La Pili (37 tahun), Sekretaris MPW PKS dan Anggota DPRD Provinsi Sulawesi Tenggara, Observasi dan Wawancara, Raha, 25 Agustus 2015.

${ }^{23}$ La Pili (37 tahun), Sekretaris MPW PKS dan Anggota DPRD Provinsi Sulawesi Tenggara, Observasi dan Wawancara, Raha, 25 Agust us 2015.

${ }^{24}$ Arsip Dewan Pengurus Wilayah (DPW) PKS Sulawesi Tenggara, Dokumentasi dan Observasi, Juni-Juli 2015. 


\section{c. Materi yang disampaikan}

Berkaitan dengan materi yang disampaikan pada proses tarbiyah, pada umumnya yaitu ajaran Islam sendiri yang terdiri dari aqidah, syariah, muamalah dan akhlak. Berbicara materi tarbiyah memiliki kurikulum tersendiri yang disesuaikan dengan jenjang kader. Meskipun demikian, materi tersebut dalam panyampaiannya tidak terikat akan tetapi selalu disesuaikan dengan situasi dan kondisi. Namun yang perlu diketahui bahwa kader harus memahami dan menamatkan seluruh materi yang tertera dalam kurikulum sebelum naik pada jenjang kader selanjutnya. ${ }^{25}$ Oleh karena itu, materi yang disampaikan ini merupakan salah satu faktor pendukung strategi dakwah PKS di Sulawesi Tenggara.

\section{d. Media dan waktu yang digunakan}

Media dan waktu yang digunakan adalah termasuk faktor pendukung strategi dakwah PKS di Sulawesi Tenggara. Media yang dimaksud disini yaitu sarana yang berupa program atau bentuk acara yang digunakan untuk merealisasikan kurikulum tarbiyah.

Berdasarkan penelitian penulis bahwa PKS memiliki sarana-sarana dan waktu yang digunakan dalam melaksanakan strategi dakwahnya antara lain: pertama, halaqah sebagai sarana pembentukan aqidah, fikrah, ibadah, akhlak, dan penguasaan amal jama'i. Jumlah normal satu halaqah maksimal 12 orang dan dipimpin oleh seorang Murabbi dan biasanya dilakukan satu kali dalam sepekan. Kedua, mabit sebagai sarana tarbiyah ruhiyah dalam bentuk menginap bersama dengan menghidupkan malam untuk memperkuat hubungan dengan Allah serta meningkatkan kecintaan kepada Rasullullah, memperkuat ukhuwah dan menambah bekalan dakwah. Hal ini didasarkan pada tingkatan jenjang kader, untuk pemula biasanya sekali dalam 3 bulan. Ketiga, rihlah merupakan suatu perjalanan rekreasi yang disiapkan untuk mencapai sasarn pemulihan dan penyegaran potensi ruhi, fikri dan jasadi. Dilaksanakan sekali dalam setahun. Keempat, daurah sebagai sarana tarbiyah fikriyah yakni forum intensif untuk mendalami suatu tema atau keterampilan tertentu. ${ }^{26}$

e. Metode yang digunakan

Metode adalah salah satu faktor pendukung utama dalam pelaksanaan strategi dakwah PKS di Sulawesi Tenggara. Karena metode merupakan cara untuk menyampaikan pesan atau materi kepada kader atau mad'u guna mencapai tujuan seperti yang telah ditetapkan.

Berdasarkan hasil penelitian penulis bahwa dalam proses menyampaikan materi atau pesan hampir semua menggunakan metode belajar yang dikenal

\footnotetext{
${ }^{25}$ Muhammad Poli ((40 tahun), Ketua DPW PKS dan Anggota DPRD Provinsi Sulawesi Tenggara, Observasi dan Wawancara, 29 Juni 2015.

${ }^{26}$ Muhammad Poli ((40 tahun), Ketua DPW PKS dan Anggota DPRD Provinsi Sulawesi Tenggara, Observasi dan Wawancara, 29 Juni 2015.
} 
secara umum yakni metode ceramah, diskusi, tanya jawab, demonstrasi, eksperimen, simulasi, partisipasi, penugasan, sosiodrama, pengembangan kelompok dan sejenisnya. ${ }^{27}$ Dan semuanya itu dipergunakan oleh para murabbi sesuai dengan obyek, jenis materi, lingkungan dan faktor lainnya.

\section{f. Masyarakat setempat}

Keterlibatan masyarakat setempat dalam mendukung strategi dakwah PKS di Sulawesi Tenggara sangat penting karena dengan adanya dukungan masyarakat setempat maka besar kemungkinan dapat memperlancar jalannya berbagai program kegiatan partai. Dalam melaksanakan program kegiatan partai di wilayah Sulawesi Tenggara, khususnya ditingkat wilayah dan daerah didukung oleh masyarakat setempat sehingga pelaksanaan program partai berjalan dengan baik.

Rekruitmen tokoh masyarakat sehingga dengan bergabungnya mereka menjadi kekuatan tersendiri bagi strategi dakwah PKS.

g. Pemerintah setempat ${ }^{28}$

Partai Keadilan Sejahtera (PKS) selain sebagai partai politik juga merupakan bagian dari lembaga sosial dan dakwah yang keberadaannya sudah diakui oleh pemerintah. Oleh karena itu, dalam kehidupan sehari-hari pemerintah setempat yang berwenang dalam lingkungan msyarakat harus ikut serta dalam mendukung kegiatan-kegiatan pembinaan dalam masyarakat agar dapat tercipta suasana lingkungan yang aman, damai, dan tentram.

Sehubungan dengan hal tersebut, ketika penulis melakukan penelitian ditemukan bahwa salah satu faktor eksternal yang mendukung jalannya programprogram atau kegiatan pembinaan dalam masyarakat yaitu adanya dukungan dari pemerintah setempat. Seperti ketika akan diadakan ta'lim terbuka, tarhib ramadhan, halal bi halal selalu didukung dan disetujui oleh pemerintah setempat sehingga kegiatan tersebut dapat berjalan dengan lancar.

\section{Faktor Penghambat Dakwah Siyasah sebagai Strategi Dakwah Partai Keadilan Sejahtera (PKS) di Sulawesi Tenggara}

Melihat perkembangan PKS yang pasang surut terutama di kanca perpolitikan maka memaksimalkan dakwah siyasah sebagai strategi dakwahnya sangat diharapkan. Oleh karena itu, dalam menjalankan strateginya tentu dibutuhkan kualitas dan kuantitas yang memadai. Dalam upaya merealisasikan strategi dakwah, tidak lepas dari adanya berbagai faktor yang mempengaruhinya. Selain faktor pendukung juga ada faktor penghambat.

\footnotetext{
${ }^{27}$ Arsip Dewan Pengurus Wilayah (DPW) PKS Sulawesi Tenggara, Dokumentasi dan Observasi, Juni-Juli 2015.

${ }^{28}$ La Aris (43 tahun), Kepala Lurah Kec. Napabalano dan Tokoh Masyarakat, Observasi dan Wawancara, 2 Agustus 2015.
} 
Terkait dengan hal tersebut, faktor penghambat dakwah siyasah sebagai strategi dakwah Partai Keadilan Sejahtera (PKS) di Sulawesi Tenggara dapat penulis uraikan sebagai berikut:

Ketidakmampuan para kader dalam memikul beban dakwah dalam perjuangan PKS yang menjadikan dakwah siyasah sebagai strategi dakwahnya merupakan tantangan tersendiri bagi internal PKS.

Berdasarkan hasil pengamatan penulis, ketika melakukan penelitian ditemukan bahwa ada beberapa hal yang menjadi penghambat strategi dakwah PKS diantaranya:

a. Kurangnya pemahaman $\operatorname{kader}^{29}$

Kurangnya pemahaman kader tentang jalan dakwah yang ditempuhnya menjadi salah satu penghambat strategi dakwah PKS. Dengan begitu mereka gugur dari jalan dakwah tersebut. Sehingga hal ini terkadang menyulitkan kader yang lain atau bahkan pergantian struktur kepengurusan secara tiba-tiba apabila dia seorang kader pengurus untuk mengisi posisi yang kosong karena akan mengakibatkan kerja-kerja dakwah menjadi terbengkala.

b. Usia kader yang relatif muda

Sebagaimana yang telah diketahui bahwa kebanyakan kader PKS berasal dari kalangan menengah dan berusia muda, sehingga tidak heran kalau PKS sering dijuluki sebagai partainya anak muda. Namun, hal tersebut menjadi salah satu faktor penghambat termasuk di Sulawesi Tenggara karena ketokohan kader dalam masyarakat belum muncul dan belum ada rekayasa untuk memunculkan kader. $^{30}$

c. Masih lemahnya komunikasi yang baik dan kontinyu dengan masyarakat

Kader PKS dituntut agar selalu memanfaatkan waktu dengan baik, berdasarkan hasil pengamatan penulis para kader PKS memiliki jam tidur empat sampai lima jam saja sehari semalam. Selebihnya itu dilakukan untuk kerja-kerja dakwah, cari nafkah dan ibadah. Dengan kata lain, produktif dalam hidup salah satu prinsip mereka. Hal ini terkadang membuat para kader kurang bertemu langsung dengan masyarakat. ${ }^{31}$

d. Adat atau tradisi masyarakat

Adat dalam suatu lingkungan masyarakat merupakan salah satu hal yang sangat penting. Karena selain bisa menjadi sebuah harmoni juga dapat menciptakan keseimbangan dalam masyarakat. Adat atau tradisi sebenarnya bisa menjadi sarana dakwah, akan tetapi adat yang masih tertanam kuat menjadi hambatan tersendiri.

Terkait dengan hal tersebut, hasil penelitian penulis ditemukan bahwa ternyata masih ada adat atau tradisi masyarakat di wilayah Sulawesi Tenggara terutama ditingkat daerah dan desa yang kuat secara turun temurun. Hal ini

\footnotetext{
${ }^{29}$ Muhammad Poli ((40 tahun), Ketua DPW PKS dan Anggota DPRD Provinsi Sulawesi Tenggara, Observasi dan Wawancara, 29 Juni 2015.

${ }^{30}$ Muhammad Poli ((40 tahun), Ketua DPW PKS dan Anggota DPRD Provinsi Sulawesi Tenggara, Observasi dan Wawancara, 29 Juni 2015.

${ }^{31}$ La Dahira (46 tahun), Ketua Bidang Dakwah Dewan Pengurus Daerah (DPD) PKS Kab. Muna Sulawesi Tenggara, Wawancara, 2 Agustus 2015.
} 
menjadi kendala tersendiri ketika mau disinergikan dengan nilai-nilai dakwah yang hendak diterapkan oleh kader-kader PKS. ${ }^{32}$

e. Letak geografis

Sulawesi Tenggara merupakan salah satu provinsi kepulauan yang unik di Indonesia. Terdapat beberapa kabupaten yang berada di wilayah kepulauan, yang mana jalan akses kesana hanya dengan kendaraan laut pula misalnya kapal fery. Hal tersebut bisa menjadi tantangan tersendiri juga bagi kader-kader PKS.

Berdasarkan hasil penelitian penulis ditemukan bahwa, letak geografis wilayah pada daerah-daerah tertentu, terutama di wilayah kepulauan ini untuk mensukseskan program-program strategis dakwah PKS menjadi kendala terutama dalam sisi waktu dan pembiayaan. ${ }^{33}$

3. Solusi Faktor Penghambat dalam Menerapkan Dakwah Siyasah Sebagai Strategi Dakwah Partai Keadilan Sejahtera (PKS) di Sulawesi Tenggara

Partai Keadilan Sejahtera (PKS) membangun fondasi-fondasi dakwahnya melalui kelompok-kelompok kecil yang secara umum disebut tarbiyah. Sebelum bermertamorfosis menjadi partai politik pun PKS sudah melaksanakan kegiatankegiatan tarbiyah tersebut sampai dengan saat ini. Inilah yang menjadi salah satu ciri khas partai dakwah ini. Oleh karena itu, setelah beberapa kali melalui perhelatan demokrasi yakni pemilu para kader terutama para petinggi partai di skala nasional mupun daerah semakin tahu peluang dan tantangan dakwah mereka ke depan. Dan untuk melewati peluang dan tantangan tersebut perlu diperkuat sisi-sisi kualitas kader agar dihasilkan barisan kader yang mampu menembus peluang dan tantangan dakwah ke depan.

Berangkat dari hasil wawancara beberapa informan dan data dokumentasi, ada beberapa hal penting yang penulis identifikasi untuk kemudian dideskripsikan sebagai solusi faktor penghambat dalam menerapkan dakwah siyasah sebagai strategi dakwah PKS di Sulawesi Tenggara.

Adapun salah satu solusi faktor penghambat dari dakwah siyasah sebagai strategi dakwah Partai Keadilan Sejahtera (PKS) di Sulawesi Tenggara yaitu dengan membangun kekokohan kader. Kekokohan yang dimaksud yaitu kader yang memiliki kekuatan, kematangan, kedewasaan secara ma'nawiyah, fikriyah, da'awiyah dan jasadiyah. Karena menurut mereka kader yang kokoh inilah yang memiliki ketajaman ruhiyah, kejernihan jiwa juga yang mempunyai keluasan ilmu pengetahuan, wawasan global dan kekuatan mengimplementasikan keilmuannya dalam realitas kehidupannya. Selain itu, kader yang memiliki kekokohan tersebut mampu tsabat dan istiqomah dalam medan dakwah meskipun gelombang ujian silih berganti menghadangnya. Dan seseorang yang memiliki kebugaran dan kesehatan jasmani, sehingga mampu mengemban beban dakwah

\footnotetext{
${ }^{32}$ La Pili (37 tahun), Sekretaris MPW PKS dan Anggota DPRD Provinsi Sulawesi Tenggara, Observasi dan Wawancara, Raha, 25 Agustus 2015.

${ }^{33}$ La Pili (37 tahun), Sekretaris MPW PKS dan Anggota DPRD Provinsi Sulawesi Tenggara, Observasi dan Wawancara, Raha, 25 Agustus 2015.
} 
dan senantiasa energik dan dinamis. Tanpa mengenal loyo dan lesu dalam merespon tantangan dakwah. ${ }^{34}$

Berikut penulis akan memaparkan langkah-langkah solutif dalam membangun kekokohan tersebut secara rinci:

1. Membangun Kekokohan Ma'nawiyah

a. Ikhlas dalam berdakwah

1) Mulailah berdoa ketika keluar rumah dan renungkan doa itu.

2) Tulis tujuan dan sasaran pada hari itu di saat keluar rumah.

3) Luruskan niat

4) Bangun muraqabah dalam hati selama melakukan pekerjaan.

b. Senantiasa memurnikan akidah dari bid'ah dan khurafat

1) Miliki dan pahami buku referensi tentang akidah Islam

2) Pahami macam syirik, bid'ah dan khurafat yang berkembang dilingkungan sosial.

c. Qiyamulail minimal tiga kali setiap pekan ${ }^{35}$

1) Berwudhu sebelum tidur

2) Bangun dengan niat dan kehendak untuk melakukan shalat lail.

d. Puasa sunnah minimal tiga kali setiap bulan

1) Miliki keinginan kuat untuk berpuasa setiap bulan

2) Pahami dan renungkan fadhilah puasa dari beberapa hadis

e. Tilawah minimal satu juz setiap hari

1) Lakukan manajemen waktu yang tepat

2) Baca fadhilah tilawah dari hadis-hadis nabi

f. Membaca ma'tsurat pagi dan sore hari

1) Luangkan sebagian waktu sesudah shalat subuh dan ashar untuk membaca ma'tsurat

2) Bawa buku ma'tsurat anda setiapwaktu

g. Tadabur Al-Quran minimal satu ayat sehari

1) Pilih dan pilah ayat-ayat yang akan ditadaburkan

2) Tulis poin-poin yang berkaitan dengan ayat

h. Sabar dalam menghadapi ujian hidup dan dakwah

1) Renungkan keutamaan sabar dalam medan dakwah

2) Baca biografi para salafus saleh yang gigih dalam memperjuangkan kebenaran

i. Senantiasa tawakal kepada Allah dalam setiap situasi dan kondisi

1) Serahkan segala urusan kepada Allah setelah berikhtiar dan berdo'a

2) Yakini bahwa manusia hanya bisa merencanakan dan Allah-lah yang menentukan

j. Senantiasa berzikir

1) Pahami manfaat dan keutamaan berzikir

\footnotetext{
${ }^{34}$ Milwan (43 tahun), Sekretaris Dewan Pengurus Daerah (DPD) Kab. Muna Sulawesi Tenggara, Observasi dan Wawancara, 25 Agustus 2015.

${ }^{35}$ Arsip Dewan Pengurus Wilayah (DPW) PKS Sulawesi Tenggara, Dokumentasi dan Observasi, Juni-Juli 2015.
} 
2) Biasakan menghiasi bibir dengan membaca kalimat thayyiban pada waktu sendiri ${ }^{36}$

Kekokohan ma'nawiyah merupakan daya dorong untuk melaksanakan kegiatan-kegiatan opersional dan beban dakwah. Kekokohan ma'nawiyah yakni membangun kekuatan ruhiyah untuk menjaga keikhlasan dalam medan dakwah partai dan kekuatan ruhiyah ini juga memiliki pengeruh besar dalam kemenangan dakwah partai dan kepercayaan masyarakat.

2. Membangun Kekokohan Fikriyah ${ }^{37}$

a. Menguasai mawad tarbiyah dengan baik

1) Koleksi buku-buku referensi tentang tema-tema tarbawiyah

2) Dengar dan perhatikan penjelasan murabbi tentang tema-tema tarbiyah

3) Diskusikan tema-tema yang ada dengan anggota lain

b. Mampu memahami tafsir dan ulumul Quran sesuai dengan madah tarbiyah

c. Mampu memahami hadis dan ulumul hadis sesuai dengan madah tarbiyah

d. Mampu berbahasa Arab dan Inggris

e. Memiliki wawasan tentang garakan-gerakan destruktif dan gerakan-gerakan dakwah lain

f. Memiliki wawasan global

1) Baca buku-buku yang memuat tema-tema teknologi informasi dan ilmu pengetahuan global

2) Hadiri seminar seputar wawasan tersebut ${ }^{38}$

Kekokohan fikriyah merupakan salah satu upaya PKS dalam mengkader karena hal tersebut menjadi tuntutan yang harus dipenuhi. Tanpa wawasan dan keilmuan yang memadai, kader dakwah tidak akan mampu berinteraksi dengan dunia kemajuan yang dihadapinya. Karena orang yang tidak memiliki apa-apa tidak akan dapat member kontribusi kepada orang lain.

3. Membangun Kekokohan Da'awiyah ${ }^{39}$

a. Buat image diri sebagai bagian dari dakwah

1) Aktif ke mesjid untuk shalat berjamaah minimal tiga kali sehari di lingkkungannya.

2) Memakmurkan majelis taklim dilingkungannya.

b. Berpartisipasi dalam rekrutmen hizb dan tajnid ikhwani

1) Pahami dengan baik aktivitas Training Orientasi Partai/taklim rutin partai dan taklim rutin kader.

2) Luangkan waktu untuk rekrutmen hizb

c. Aktif melakukan dakwah fardhiyyah dilingkungan keluarga dan sosial

1) Mulai memilih dan memilah anggota keluarga dan tetangga yang bisa dipengaruhi.

\footnotetext{
${ }^{36}$ Arsip Dewan Pengurus Wilayah (DPW) PKS Sulawesi Tenggara, Dokumentasi dan Observasi, Juni-Juli 2015.

${ }^{37}$ Milwan (43 tahun), Sekretaris Dewan Pengurus Daerah (DPD) Kab. Muna Sulawesi Tenggara, Observasi dan Wawancara, 25 Agustus 2015.

${ }^{38}$ Arsip Dewan Pengurus Wilayah (DPW) PKS Sulawesi Tenggara, Dokumentasi dan Observasi, Juni-Juli 2015.

${ }^{39}$ Milwan (43 tahun), Sekretaris Dewan Pengurus Daerah (DPD) Kab. Muna Sulawesi Tenggara, Wawancara, 25 Agustus 2015.
} 
2) Lakukan saling member hadiah di saat memulai pendekatan.

d. Menjaga nilai-nilai da'awiah dalam keluarga

1) Lakukan kontroling setiap anggota keluarga berkaitan dengan kewajibankewajibannya.

2) Lakukan taklim keluarga minimal satu kali seminggu.

e. Memiliki skill rekayasa sosial da'awi ${ }^{40}$

1) Ikuti pelatihan seputar skill rekayasa sosial

2) Analisa peta masyarakat sebelum melakukan rekayasa sosial da'awi

3) Rencanakan strategi dan langkah-langkah operasional dakwah

f. Mampu membangun jaringan dengan tokoh-tokoh sentral

1) Data nama-nama tokoh yang ada dalam masyarakat dan pahami background mereka masing-masing.

2) Lakukan silaturrahmi dengan mereka dan hadiri pertemuan-pertemuan yang melibatkan mereka.

g. Istiqomah di jalan dakwah

1) Pahami urgensi berdakwah dan bahwasanya medan dakwah banyak dipenuhi batu-batu ujian.

2) Pahami dampak istiqomah dan tidak istiqomah dalam berdakwah sera perjuangan memerlukan pengorbanan. ${ }^{41}$

Kekuatan ma'nawi dan fikri merupakan sarat mutlak dan bekal kader dalam medan dakwah. Kecerdasan jiwa dan kebeningan hati yang mencerminkan ketegaran iman dan ikhlas merupakan bensin yang tidak pernah kering dalam menghidupkan roda dakwah sepanjang hidupnya

4. Membangun Kekokohan Jasadiyah ${ }^{42}$

a. Menjaga performance

1) Menjaga penampilan yang baik adalah anjuran agama

2) Yakin bahwasanya rapi dalam berpakaian adalah salah satu faktor keberhasilan dakwah.

b. Berolahraga minimal 20 menit setiap hari

1) Yakini bahwa kebugaran ditunt ut dalam kerja dakwah

c. Menjaga kebersihan

1) Perhatikan kebersihan pakaian sebelum memakainya

2) Buat jadwal kebersihan rumah dan lingkungan

d. Mengikuti pola hidup sehat

Untuk mengimplementasikan kerja-kerja dakwah dan memikul beban dakwah sangat diperlukan energi yang optimal dan kebugaran jasmani. Hanya badan yang sehat disamping sehat rohani dan fikri yang mampu memikul beban dakwah. ${ }^{43}$

\footnotetext{
${ }^{40}$ Arsip Dewan Pengurus Wilayah (DPW) PKS Sulawesi Tenggara, Dokumentasi dan Observasi, Juni-Juli 2015.

${ }^{41}$ Arsip Dewan Pengurus Wilayah (DPW) PKS Sulawesi Tenggara, Dokumentasi dan Observasi, Juni-Juli 2015.

${ }^{42}$ Milwan (43 tahun), Sekretaris Dewan Pengurus Daerah (DPD) Kab. Muna Sulawesi Tenggara, Observasi dan Wawancara, 25 Agustus 2015.

${ }^{43}$ Arsip Dewan Pengurus Wilayah (DPW) PKS Sulawesi Tenggara, Dokumentasi dan Observasi, Juni-Juli 2015.
} 
Pengelolaan tarbiyah harus bersifat interaktif artinya setiap kader harus diinteraksikan dengan realitas kehidupan sehari-hari. Nilai-nilai dan pemahaman yang dibentuk dalam halaqah harus mampu dibimbing pada penerapan amalnya di lapangan, pada kehidupan pribadi, kehidupan keluarga, dan lain sebagainya. Untuk itu, seorang murabbi tidak boleh membatasi interaksinya dengan mutarabbi di ruang-ruang halaqah tapi dia senantiasa bergaul dengan mereka di berbagai kesempatan dan ruang kehidupan. Kedua, pengelolaan terbiyah haruslah bersifat responsif. Yaitu ada sikap positif yang dibangun untuk peka terhadap dinamika kehidupan di sekitar dan mampu meresponnya. Halaqah akan diramaikan dengan laporan pandangan mata para mutarabbi tentang apa yang terjadi di lingkungan kehidupan mereka. Reportase ini didiskusikan, disimpulkan dan direspon atau program dakwah yang dilaksanakan secara amal jama'i. setiap kader dimotivasi atau diberi kepercayaan untuk mendayagunakan semua potensi yang dimilikinya dalam menjalankan program itu. Sehingga terdorong ide-ide kreatif, inovatif dan sifat dinamis pada diri mereka. ${ }^{44}$

Selanjutnya pengelolaan tarbiyah harus mampu memunculkan iklim fastabiqul khairat atau iklim berkompetisi. Karena dakwah tidak berjalan diruang kosong, tetapi sesuai sunnahnya berjalan di tengah medan pertarungan yang luas dan kompleks. Disekelilingnya begitu banyak unsur-unsur kekuatan kebatilan yang ingin memaksakan kehendaknya, dan secara serius bekerja untuk menghadang dakwah. Telah begitu banyak kerusakan dan fitnah yang mereka ciptakan. ${ }^{45}$ Demikian pula dakwah dihadirkan Allah untuk melenyapkan semua kerusakan dan fitnah di muka bumi ini. Sesuatu yang hanya bisa berwujud, apabila tersedia barisan kader dakwah yang memiliki semangat fastabiqul khairat untuk meraih kemenangan dari Allah swt.

\section{KESIMPULAN}

Faktor pendukung dakwah siyasah sebagai strategi dakwah Partai Keadilan Sejahtera (PKS) di Sulawesi Tenggara meliputi partisipasi kader dalam memanfaatkan partai politik, kompotensi kader, materi yang disampaikan, media dan waktu yang digunakan, metode yang digunakan, adanya dukungan dari masyarakat dan pemerintah setempat. Adapun faktor penghambat meliputi kurangnya pemahaman kader, usia kader yang relatif muda, masih lemahnya komunikasi yang baik dan kontinyu dengan masyarakat, adat atau tradisi masyarakat dan letak geografis. Dan solusi faktor penghambat dalam menerapkan dakwah siyasah sebagai stategi dakwah Partai Keadilan Sejahtera (PKS) di Sulawesi Tenggara yakni dengan membangun kekokohan kader. Langkah-langkah solutif dalam membangun kekokohan tersebut antara lain: membangun kekokohan ma'nawiyah dalam hal ini membangun kekuatan ruhiyah untuk menjaga keikhlasan dalam medan dakwah. Kekokohan fikriyah yakni mempunyai wawasan dan keilmuan yang memadai agar mampu berinteraksi

\footnotetext{
${ }^{44}$ Milwan (43 tahun), Sekretaris Dewan Pengurus Daerah (DPD) Kab. Muna Sulawesi Tenggara, Observasi dan Wawancara, 25 Agustus 2015.

${ }^{45}$ Milwan (43 tahun), Sekretaris Dewan Pengurus Daerah (DPD) Kab. Muna Sulawesi Tenggara, Observasi dan Wawancara, 25 Agustus 2015.
} 
dengan dunia yang semakin maju. Selain itu, membangun kekokohan da'awiyah maksudnya setelah kokoh ruhiyah dan fikriyahnya maka selanjutnya menghidupkan roda dakwah sepanjang hidup. Serta kekokohan jasadiyah yaitu energi yang optimal dan kebugaran jasmani agar dapat melaksanakan dan memikul beban dakwah.

\section{DAFTAR PUSTAKA}

Arsip Dewan Pengurus Wilayah (DPW) PKS Sulawesi Tenggara, Dokumentasi dan Observasi, Juni-Juli 2015.

Amin, Muliaty. Metodologi Dakwah, Cet.I; Alauddin University Press: Makassar, 2013.

Idris, Malik. Strategi Dakwah Kontemporer, Cet.I; Makassar: Sarwah Press, 2007.

Muliadi. Dakwah Inklusif, Cet.I; Makassar: Alauddin University Press, 2013.

--------. Dakwah Efektif: Prinsip, Metode dan Aplikasinya, Makassar: Alauddin University Press, 2012.

Kusnawan, Aep. Ilmu Dakwah (Kajian Berbagai Aspek), Bandung: Pustaka Bani Quraisy, 2004

"PKS Visi dan Misi", Situs Resmi Dewan Pengurus Pusat Partai Keadilan Sejahtera. www. Pks.or.id/mobile/content.html? (19 Mei 2015).

\section{Sumber Wawancara}

La Ode Muh. Dasnah (42 tahun), Ketua Bidang Dakwah dan Staf Ahli DPRD Provinsi Sulawesi Tenggara, Observasi dan Wawancara, 25 Juni 2015.

La Pili (37 tahun), Sekretaris MPW PKS dan Anggota DPRD Provinsi Sulawesi Tenggara, Observasi dan Wawancara, Raha, 25 Agustus 2015.

Muhammad Poli ((40 tahun), Ketua DPW PKS dan Anggota DPRD Provinsi Sulawesi Tenggara, Observasi dan Wawancara, 29 Juni 2015.

La Dahira (46 tahun), Ketua Bidang Dakwah Dewan Pengurus Daerah (DPD) PKS Kab. Muna Sulawesi Tenggara, Wawancara, 2 Agustus 2015.

La Pili (37 tahun), Sekretaris MPW PKS dan Anggota DPRD Provinsi Sulawesi Tenggara, Observasi dan Wawancara, Raha, 25 Agustus 2015.

Milwan (43 tahun), Sekretaris Dewan Pengurus Daerah (DPD) Kab. Muna Sulawesi Tenggara, Observasi dan Wawancara, 25 Agustus 2015. 